\title{
AdDITIONAL FEATURES FOR THE RECENTLY DESCRIBED Pinguicula (Lentibulariaceae) SPecies From Spain
}

\author{
AYMERIC RocCIA • Chambéry • France • aymeric.roccia@live.fr
}

Keywords: Pinguicula casperiana, Lentibulariaeae, Serranía de Cuenca, Spain.

Abstract: Two new butterwort species, Pinguicula casperiana and P. tejedensis, from Central Spain have been recently described, and the name $P$. submediterranea has been resurrected in the same publication. My article describing " $P$. conquensis" was under review at that time and this plant is exactly the same as P. casperiana. As it gives additional morphological diagnostic characters, it is worth bringing it to everyone's attention for a better understanding of this species. Additional comments are made about $P$. submediterranea and $P$. tejedensis as those populations were also studied in my article: those names are here considered later synonyms of $P$. dertosensis. Pinguicula casperiana raises to eleven the number of Pinguicula species from Spain, being the sixth endemic to the Iberian Peninsula.

\section{Introduction}

With approximately 360 species, Lentibulariaceae Rich. is the most diverse family of carnivorous plants (Fleischmann \& Roccia 2018). Among these, the genus Pinguicula L. accounts for ca. 105 species (Juárez-Gutiérrez et al. 2018; Casper 2019; Zamudio \& Vega 2019; Zamudio et al. 2019; Casper et al. 2020). Mexico and the Mediterranean basin represent the two main diversity centers of the genus (Fleischmann \& Roccia 2018).

The last revision of the Pinguicula species in Spain and Portugal (Blanca et al. 1999) and the Flora Iberica (Blanca 2001) list nine species in the Iberian Peninsula: P. alpina L., P. dertosensis (Cañig.) Mateo \& M. B. Crespo, P. grandiflora Lam., P. longifolia Ramon ex DC., P. lusitanica L., P. mundi Blanca, Jamilena, Ruíz-Rejón \& Reg. Zamora, P. nevadensis (Lindb.) Casper, P. vallisneriifolia Webb, and P. vulgaris L. A tenth new species was added in 2018, P. saetabensis M. B. Crespo, Mart.-Azorín \& M. A. Alonso (Crespo et al. 2018). Populations from central Spain have been a matter of debate: they were treated as belonging to P. mundi (Blanca et al. 1999; Blanca 2001) or to P. dertosensis (Roccia et al. 2016), or as "morphologically distinct" (Crespo et al. 2018).

While reviewing herbarium material, pictures from botanical fieldtrip to this region, and cultivated material, it became clear that these populations represent a new species, planned to be named "Pinguicula conquensis". The article has been submitted to a peer-reviewed journal and it was only a matter of days before it should have been published. However, in the meantime, another article was realised describing two new species, $P$. casperiana and $P$. tejedensis, and resurrecting the name $P$. submediterranea (Crespo et al. 2020). "Pinguicula conquensis" and P. casperiana are in fact one and the same species and my article got rightly rejected for that reason. Nonetheless, it is worth adding the taxonomical features forecast in my article to the ones of Crespo et al. (2020) for a better understanding of this species.

Material \& methods

Morphological analysis for the description of the new species is based on field observations during a fieldtrip to Spain in 2010, on examination of cultivated material, herbarium specimens held at 
ALBA, BC, GADC, JACA, MA, MAF, and P (Thiers 2019) and in situ photographs of independent observers. The distribution map was drawn based on all those records using QGIS software in its 3.12.1 version. Conservation status is discussed following the IUCN (2012) Red List categories and criteria.

Results

Below is the description of "Pinguicula conquensis" as it was submitted to the peer-reviewed journal:

\section{Diagnosis}

Pinguicula casperiana is morphologically close to $P$. dertosensis and $P$. mundi. It differs from $P$. dertosensis by i) its divergent corolla lower lip lobes (vs. overlapping in P. dertosensis), ii) its calyx lower lip lobes fused on $1 / 2$ or more of their length (vs. free to fused on less than $1 / 2$ of their length in $P$. dertosensis), iii) the flat to slightly involute margin of its spring leaves (vs. involute margins in $P$. dertosensis), iv) its ovoid capsules with pointed tip (vs. rounded without prominent tip in $P$. dertosensis), and v) its bigger (0.65-0.8 $\mathrm{mm}$ long) and more rectangular seeds with micropylar appendage (vs. smaller (0.5-0.6 mm long) and subglobose to ovoid seeds without micropylar appendage in $P$. dertosensis) (Fig. 2). It differs from $P$. mundi by i) having ovoid capsules with pointed tip (vs. rounded to subglobose in $P$. mundi), ii) its shorter spur, about $1 / 3$ of the whole corolla length (vs. about $1 / 2$ in $P$. mundi), iii) its acute triangular calyx lobes (vs. rounded to subobtuse elliptic calyx lobes in $P$. mundi), iv) its shorter (up to $7(-12) \mathrm{cm}$ long) summer leaves (vs. up to $18.5 \mathrm{~cm}$ long in $P$. mundi) and v) its smaller (0.65-0.8 mm long) seeds with micropylar appendage (vs. bigger (0.8-1.0 $\mathrm{mm}$ long) seeds without micropylar appendage in P. mundi) (Fig. 4). Additionally, the three species occur in distinct geographic areas (Fig. 3).

\section{Etymology}

Pinguicula casperiana was planned to be named "P. conquensis" after the Serranía de Cuenca, where it occurs. "conquensis" is an adjective referring to the town of Cuenca, that gives its name to the Serranía de Cuenca. "casperiana" is a tribute to S. Jost Casper.

Type material planned for "Pinguicula conquensis"

SPAIN • Cuenca, Beteta, Hoz de Beteta; 30TWK79; 1100 m; 09 Jun. [19]89; Gamarra, Garilleti \& F. Lara s. n.; holotype: MA[MA-01-00472045] photo !; isotype: MA[MA-02-00472045] photo!.

\section{Description (Fig. 1-3)}

Small perennial herb with slender white roots, overwintering as a hibernaculum. Leaves arranged in a rosette emerging from the ground; spring leaves (before anthesis) (4-)5-8 in number, yellow-greenish, sometimes tinged with red, adpressed on the ground, shortly petiolate, oblongelliptic, abaxially glabrous, adaxially densely covered with short stipitate and sessile glands, with flat to slightly involute margins and a rounded apex, 2.5-3.6 cm long and 1.1-1.8 cm wide; summer leaves (after anthesis) different from spring leaves, (3-)4-6(-8) in number, yellow-greenish, sometimes tinged with red, semi erected, shortly petiolate, obovate, abaxially glabrous, adaxially densely covered with short stipitate and sessile glands, with revolute margins and a rounded apex, $4.56 .9(-$ $11.9) \mathrm{cm}$ long and 1.6-2.0(-2.5) cm wide. Flower scapes 1-3(-4), 6.9-7.5 cm long, terete, 1-flowered, yellow-greenish and sparsely glandular at the base, red-violet and densely glandular near the flower. 


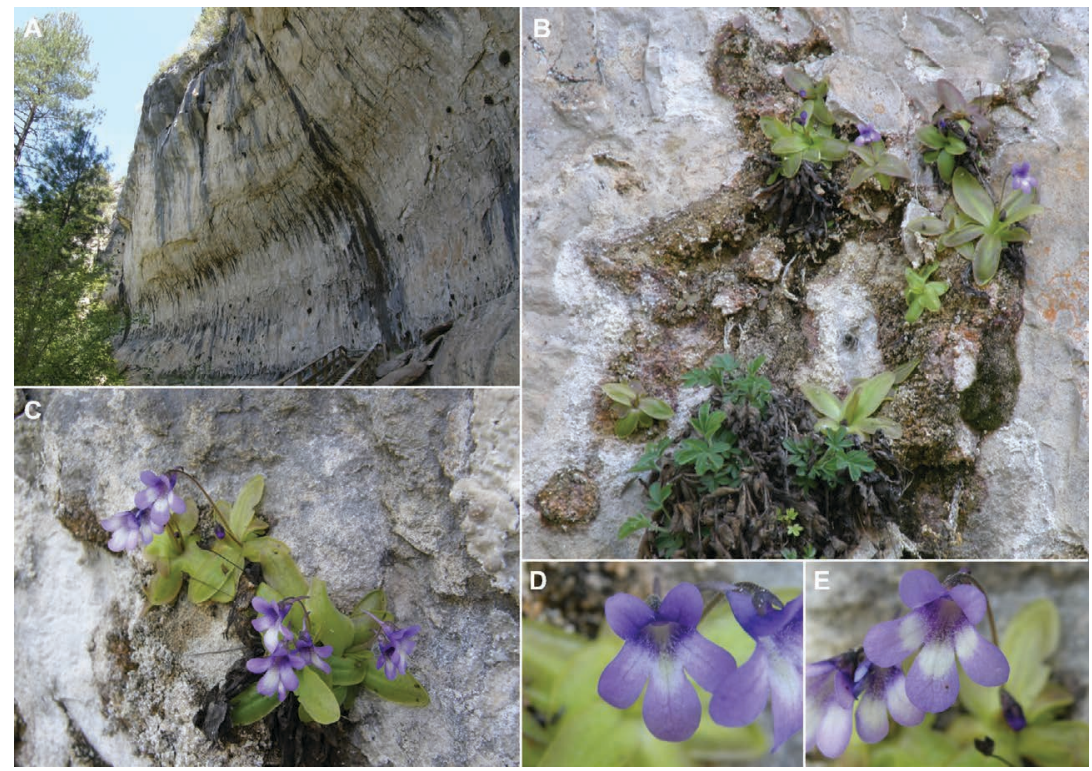

Figure 1: Pinguicula casperiana M.B.Crespo, Mart.-Azorín, M.Á.Alonso \& L.Sáez at the Huelga de Don Juan location. A: vertical limestone cliffs, typical habitat for this species. B: plants growing in a thin layer of tufa concretion and moss, associated with Potentilla caulescens L. C: habit. D, E: front views of two flowers, showing variation.

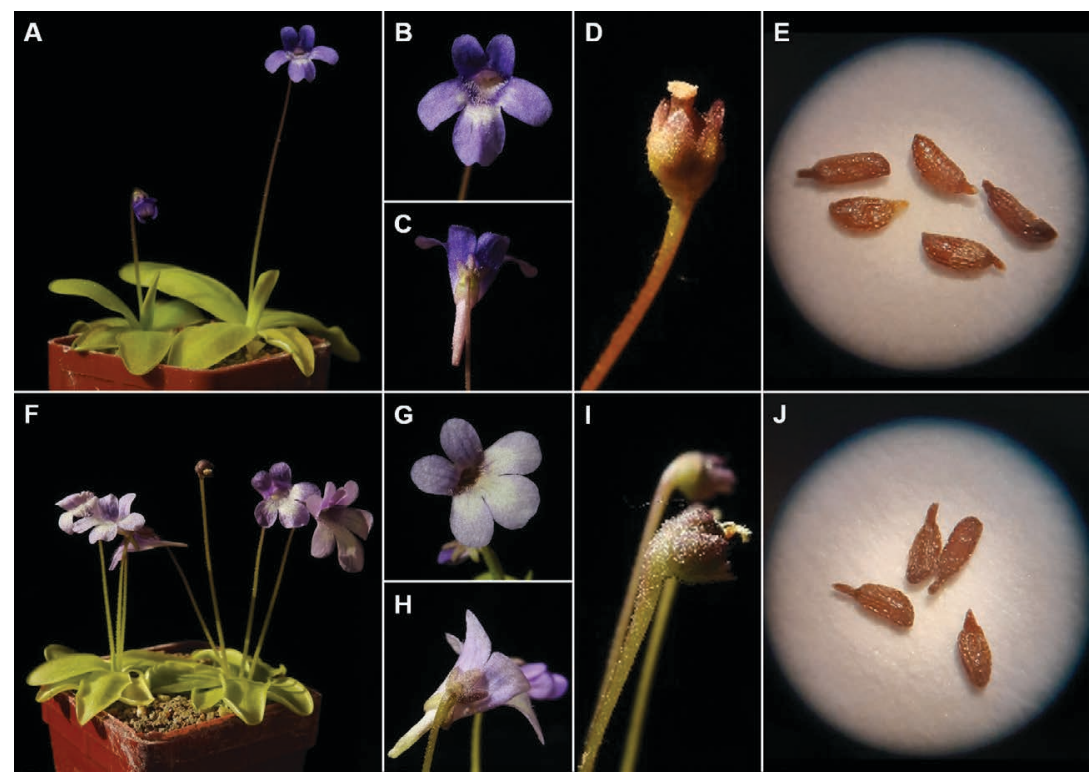

Figure 2: Comparison between Pinguicula casperiana M.B.Crespo, Mart.-Azorín, M.Á.Alonso \& L.Sáez (A-E) and P. dertosensis (Cañig.) Mateo \& M. B. Crespo (F-J). A, F: habit. B, G: front view of the flower. C, H: flower viewed from above. D, I: seedpod. E, J: seeds (same magnification (X20) was used for both pictures). 


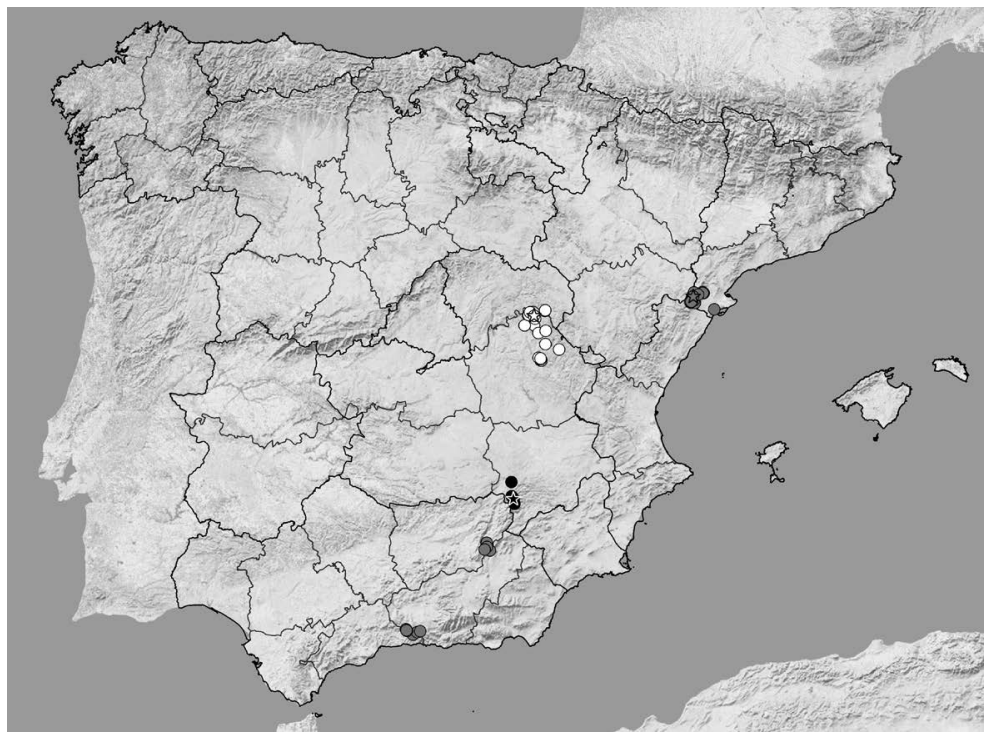

Figure 3: Distribution map of the three species treated in this study: white dot, Pinguicula casperiana M.B.Crespo, Mart.-Azorín, M.Á.Alonso \& L.Sáez; grey dot, P. dertosensis (Cañig.) Mateo \& M. B. Crespo; black dot, P. mundi Blanca, Jamilena, Ruíz-Rejón \& Reg. Zamora. Stars indicate the type locations of each species.

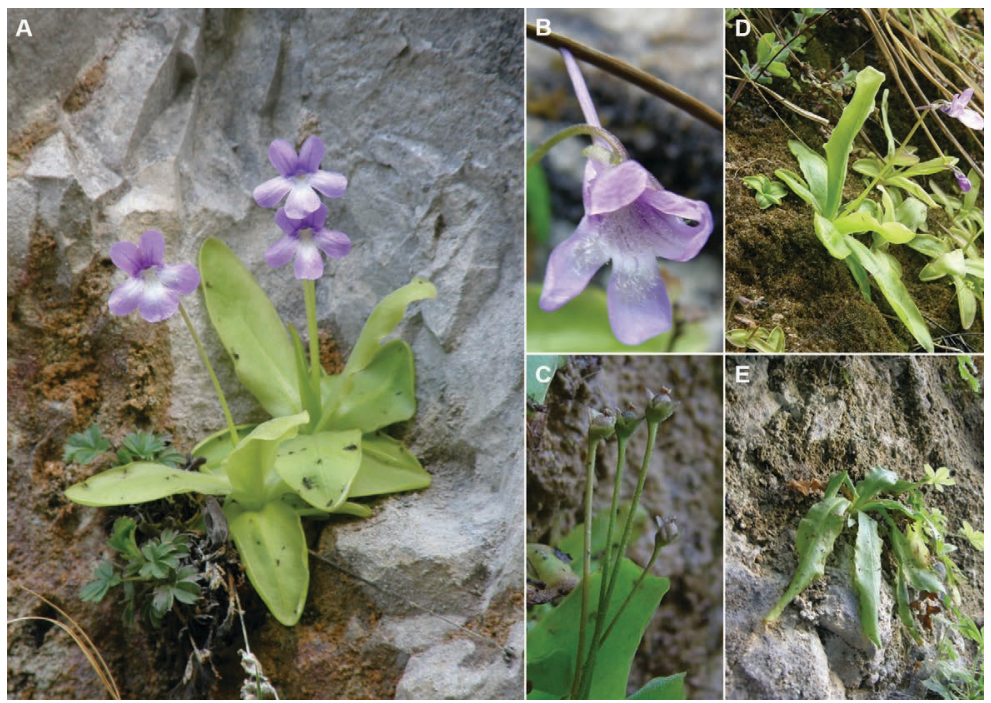

Figure 4: Pinguicula mundi Blanca, Jamilena, Ruíz-Rejón \& Reg. Zamora at its type location, for comparison with P. casperiana M.B.Crespo, Mart.-Azorín, M.Á.Alonso \& L.Sáez (Figs. $1 \&$ 2). A: habit. B: three quarter view of the flower showing the long spur. C: seedpods. D: flowering plant showing the first elongated summer leaves. E: plant at the end of the growing season, showing the typical elongated summer leaves. C from Oliver Gluch, all others from the author. 
Calyx bilabiate, 5-lobed, violet, densely covered with stipitate glands, persistent during fructification; 3 upper lip lobes triangular-ovate, with an acute to subacute apex, 3.0-4.0 mm long, 1.0-1.5 $(-2.0) \mathrm{mm}$ wide, divided to near the base; 2 lower lip lobes ovate, with an acute to subacute apex, 3.0-4.5 mm long, (1.0-)1.5-2.0 mm wide, united from the base on $c .1 / 2$ of their length, subparallel to slightly divergent. Corolla bilabiate, 5-lobed, 20-30 mm long (spur included), blue-violet in its overall, with a $90-110^{\circ}$ opening angle; 2 upper lip lobes blue-violet, sometimes marked with a dark blue-violet vein at the base, oblong, with a rounded apex, 4.0-5.5(-7.5) $\mathrm{mm}$ long, 3.0-4.5(-7.0) $\mathrm{mm}$ wide; 3 lower lip lobes blue-violet on the distal part, white on the proximal part (sometimes the lateral lobes completely blue-violet) and sometimes marked with dark blue-violet veins near the throat, bearing $c .0 .75 \mathrm{~mm}$ long white clavate hairs on the proximal part, the lateral ones oblong-obovate with a rounded apex, longer than wide, 5.0-8.0(-10.0) $\mathrm{mm}$ long, 4.0-7.5 mm wide, the middle one larger than the lateral ones, obovate with a rounded apex, sometimes with a yellow spot at the very base, 7.5-11.0 mm long, 6.0-9.0(-11.0) $\mathrm{mm}$ wide, divergent, not overlapping, with non-waving margins. Throat totally dark violet, except a thin whitish band on top of the middle lobe of the lower corolla lip, bearing c. $0.75 \mathrm{~mm}$ long white clavate hairs. Tube medium-sized, 5.5-8.5(-11.5) mm long, (4.0-)6.0-8.5(-10.5) mm wide, broadly funnel-shaped, blue-violet near the corolla lobes, violet tinged with red near the spur and whitish with dark violet veins on the lower side, sparsely covered by stipitate glands on the outer side. Spur blue-violet to red-violet, medium-sized, 5.5-7.0(-9.5) mm long, subulate, straight to slightly curved downwards, with an acute and sometimes slightly bifid apex, sparsely covered by stipitate glands on the outer side. Stamens $2, c .2 \mathrm{~mm}$ long; filaments $c$. $1.5 \mathrm{~mm}$ long, white, curved, surrounding the ovary; anthers $c .0 .5 \mathrm{~mm}$ long, light yellow, $+/$ - confluent, roofed by the stigma lower lip lobe. Pollen light yellow, aperture not studied. Ovary pale green, subglobose, sessile, covered by short stipitate glands, c. $1.5 \mathrm{~mm}$ in diameter, 2-carpellate, 1-loculate, ending in a short style; central placentation free, with numerous free sessile ovules. Stigma white tinged with violet, short, 2-lobed, with crested upper surfaces, persistent on the fruit; the lower lobe ovale, c. $2 \mathrm{~mm}$ wide, fringed; the upper lobe much smaller, narrowly triangular, c. 0.75 $\mathrm{mm}$ long, not fringed. Capsule yellow-greenish at the base, usually tinged with red mostly near the tip, ovoid with acute tip, 3.0-4.5 $\mathrm{mm}$ long and 2.0-2.6 $\mathrm{mm}$ large, sparsely covered by short stipitate glands; maroon when mature and then dehiscent. Seeds brown, elliptic to oblong, 650-800 $\mu \mathrm{m}$ long, 230-300 $\mu \mathrm{m}$ thick, stipitate with a 110-135 $\mu \mathrm{m}$ long funicle, outer coat reticulate with subrounded to ovale interspaces, with a single very short micropylar appendage (10-30 $\mu \mathrm{m}$ long). Chromosome number $2 \mathrm{n}=64$ (Casper \& Stimper 2009).

\section{Phenology}

Pinguicula casperiana starts flowering in April and can flower up to June.

\section{Habitat and ecology}

Pinguicula casperiana is typically found on vertical limestone cliffs, in deep humid gorges, at an altitude of 860-1220 $\mathrm{m}$ a.s.l. Plants are growing in a thin layer of tufa concretion and moss, accumulating in rock crevasses where water seeps from the cliff. It is usually growing alone but can shares such habitat mainly with Potentilla caulescens L., and sometimes with Adiantum capillusveneris L. (Fig. 1).

\section{Distribution}

Pinguicula casperiana is endemic to the Serranía de Cuenca, in central Spain. Most populations occur in the Cuenca province, and a few locations are also known in the Guadalajara province 
(Fig. 3). Up to now, no reference to its presence in the nearby Teruel province have been found, but it has to be searched in the east of this province.

It has been observed a morphological gradient for Pinguicula casperiana leaf along its distribution range: to the north, summer leaves are different from spring leaves (anisophyllous), being longer and with revolute margins, while towards south, they tend to be rather identical to spring leaves (heterophyllous), being shorter and with involute margins.

\section{Conservation status}

It was not possible to investigate the number of plants in each known location in the timeframe of this study, so that Pinguicula casperiana should be classified at DD (data deficient) (IUCN 2012). However, comparing photographs of the same sites (Huelga de Don Juan and Hoz de Priego) taken several years apart, it is obvious that the number of plants decreases as the cliffs are becoming drier. The vulnerability of Pinguicula casperiana has thus to be further investigated.

Additional specimens examined

Pinguicula casperiana:

Herbarium vouchers:

SPAIN - Cuenca • Beteta, Cañon del Tajo, Estrecho del Horcajo; 30TWK874959; 1130 m.; paredones calizos hacia el W.; 08 Aug. 1997; L. M. Ferrero, L. Medina LM726; MA[MA-01-00594441] photo! • Fuerte-Escusa, hacia Poyatos, balma al pie del rio Escalvas; (30T WK77); 23 Jun. 1983; Benedi, Blanché, Molero \& Vallès s. n.; BC[BC-652886] photo! • Ib., 23 Jun. 1983; Benedí, Blanché, Molero \& Vallès s. n.; MA[MA-01-00334328] photo! • Ib.; 23 Jun. 1983; Benedí, Blanché, Molero \& Vallès s. n.; MAF[122615] photo! • Hoz de Beteta; En los muros rocosos humedos calizos; 11 Jul. 1932; Prof. A. Caballero s. n.; MA[MA-01-00115271] photo! • Ib.; común en las fuentes y sitios húmedos; 11 Apr. 1933; Prof. A. Caballero s. n.; MA[MA-01-00115276] photo! • Hoz de Beteta, fuete de los Frenos; 30TWK79; ad 1100 m; in humidis calcareis; 02 Aug. 1975; Fernández Casas \& García Guardia 761; MA[MA-01-00394319] photo! • Ib.; 02 Aug. 1975; Fernández Casas \& García Guardia 761; MA[MA-02-00394319] photo! • Ib.; 02 Aug. 1975; Fernández Casas \& García Guardia 761; MA[MA-01-00439461] photo! • Hoz de Tragavivos; 30T WK78; 990m; calizas liasicas; 26 Jul. 1978; G. López 773bis GF; MA[MA-01-00439051] photo! • Huerta del M., Collado Bajo; 01 Jul. 2017; José Fajardo \& Alonso Verde s. n.; ALBA[10746] photo! - Guadalajara - Peralejos de las Truchas, paredones calizos hacia el SW sobre la pista del Tajo; 30TWK868976; 1120m.; 08 Aug. 1997; L. M. Ferrero y L. Medina LM727; MA[MA-01-00594442] photo! • Poveda de la Sierra, barranco del Horcajo; 300587158 4495363, DATUM SPWGS84; 1250 m; paredones calizos rezumantes; 02 Jun. 2012; C. Aedo, L.M. Ferrero, J. García \& L. Medina LM6270; MA[MA-01-00867494] photo!.

Populations visited by the author:

SPAIN - Cuenca • Beteta, Fuente de los Tilos; 1100 m; 18 May 2010; Aymeric Roccia’ pers. observ. - Beteta, Huelga de Don Juan; 18 May 2010; Aymeric Roccia's pers. observ. • Beteta, paredes frente a la Fuente de los Tilos; 1100 m; 18 May 2010; Aymeric Roccia's pers. observ. $\bullet$ Fuertescusa, Cueva del Aire; 977 m; 18 May 2010; Aymeric Roccia's pers. observ. • Priego, Hoz de Priego, site 1; 18 May 2010; Aymeric Roccia’s pers. observ. • Ib., site 2; 18 May 2010; Aymeric Roccia’s pers. observ. Photographs examined:

SPAIN - • Sierra de Cuenca; 02 May 2010; Jean-Marc Moingeon's pers. observ. - Cuenca • 15 Jun. 2018; Victor Mol's pers. observ. • Beteta, Fuente de los Tilos; Aug. 2018; Eric Partrat's \& Laurent Legendre's pers. observ. • Beteta, Huelga de Don Juan; Aug. 2018; Eric Partrat's \& Laurent Legen- 
dre's pers. observ. • Hoz de Beteta; 1200 m; Apr. 2004; Eric Partrat's, Jean-Rémi Fiéfort's \& Serge Lavayssière's pers. observ. Palomera, Molinos de Papel; Aug. 2018; Eric Partrat's \& Laurent Legendre's pers. observ. Priego, Hoz de Priego; Aug. 2018; Eric Partrat's \& Laurent Legendre's pers. observ. • Uña, Rincón de Uña; Aug. 2018; Eric Partrat's \& Laurent Legendre's pers. observ.

\section{Pinguicula dertosensis:}

Herbarium vouchers:

SPAIN - • Massis del Ports, vers el Barranc de la Guimerana, limit termes de LA SÉNIA (Montsià) i BESEIT (Matarranya); 31T BF61; 820 m; 03 Aug. 1967 ; L. de Torres s. n.; BC[BC-905331] photo ! - Jaén - Cazorla: barranco de Valdecazores; 30SWG1499; 1460 m; 30 May 1976; González Rebollar, Muñoz Garmendia \& Soriano 3833; MA[MA-01-00479890] photo! • Cazorla : barranco del Guadalentín; 30SWG1495; 1300 m; ribera; 25 May 1975, González Rebollar, Muñoz Garmendia \& Soriano 3829; MA[MA-01-00479893] photo! • Ib., 18 Jun. 1975; González Rebollar, Muñoz Garmendia \& Soriano 3830; MA[MA-01-00479892] photo! • Ib.; 25 Sep. 1975; González Rebollar, Muñoz Garmendia \& Soriano 3831; MA[MA-01-00479891] photo! • Sierra de Cabrilla; rochers humides et exposés au soleil, sur le calcaire; Jun. 1906; Elisée Reverchon 1429; P[P02982059] photo! • Ib.; Jun. 1906; Elisée Reverchon 1429; P[P02982060] photo! - Tarragona • Pista de Fredes al Monte Caro, barranco de Rafalgari; 4044'54"N-0 12'53"E, 30TBF6414; 1020 m; 08 Jun. 1999; C. Aedo, I. Aizpuru, J. Aldasoro, S. Castroviejo, C. Fabregat, P. Fernández, J. Forcadell, M. García, X. Giraldez, J. Güemes, J. Jiménez, S. López, G. Mateo, F. Muñoz, C. Navarro, J. Ninot, J. Pedrol, A. Prunell, E. Rico, Ll. Sáez, I. Soriano, R. Tavera \& M. Velayos CN -2449; MA[MA-01-00626738] photo! • Ports de Tortosa, Barranc de Salt de Cabrit; 29 Jun. 1917 ; Font Quer s. n.; BC[BC-53082] photo! • Ports de Tortosa: La Sénia, Vall de la Fou, Cova del Angels; 600 m; in Adiantium, rup. N.; 18 Jun. 1956 ; J. Cañigueral, A et O. de Bolós et FO. s. n.; BC[BC-148968] photo! • Tortosa, Roquetas, barranco de la Caramella; 40 48'17" $\mathrm{N} \mathrm{00} 23^{\prime} 15^{\prime \prime} \mathrm{E}$, datum WGS84; $242 \mathrm{~m}$; matorral xerófilo bajo y cauce de arroyo, substrato calizo; 13 Apr. 2011; T. Buira, J. Calvo \& A. Quintana AQ4365; MA[MA-01-00837334] photo! - Teruel • Beceite, Alto Matarrana; 31TBF6520; 750-800 m; Cantil y parte alta con "Arbutus unedo"; 10 Apr. [19]90; P. Montserrat s. n.; JACA[0060390] photo! • Puertos de Beceite, in confinibus Aragoniae et Catal., pr. Font del Teix, in initio Barranc del Parrisal; Apr. 1935; Bartomeus s. n. ; holotype: BC[BC-87830] photo!.

Populations visited by the author:

SPAIN - Tarragona - Roquetes, Cascada de la Caramella; 13 May 2010; Aymeric Roccia's pers. observ.

Photographs examined:

SPAIN - Castellón • Fredes - Rosell, 09 May 2015; Guillem Palomo's pers. observ. • Tinença de Benifassà; s. d.; José Quiles’ pers. observ. - Granada • Los Barrancones; 23 May 2014; Christophe Maerten's pers. observ. $\bullet$ Rio Cebollon entre la Cuerda de los Morros y la Loma del Mono; 03 Jun. 2012; Arielle \& Enric Marti’s pers. observ. - Jaén - Cazorla, Torcales del Lobo; a $1750 \mathrm{~m}$ de altitud; 02 May 2014; Alfredo Benavente Navarro’s pers. observ. - Málaga • Sierra Tejeda, El Robledal; 02 Jul. 2008; Joaquín Ramírez's pers. observ. - Tarragona • Caramella Schlucht; 23 Apr. 2004; Oliver Gluch's pers. observ. - Montsià; 13 Apr. 2017; unknown's pers. observ. • Roquetes, Font de Cova Avellanes; Aug. 2018; Eric Partrat's and Laurent Legendre's pers. observ. • Tortosa; 25 Apr. 2013; Jean-Marc Moingeon's pers. observ.

Pinguicula mundi:

Herbarium vouchers: 
SPAIN - Albacete - Cascades ou choros près Riopar dans la Sierra de Segura; 30 Jun. 1850; E. Bourgeau 647; P[P02982056] photo! • Ib.; 30 Jun. 1850; E. Bourgeau 647; P[P02982057] photo! - Ib.; 30 Jun. 1850; E. Bourgeau 647; P[P02982061] photo! • Ib. ; 30 Jun. 1850; E. Bourgeau 647; $\mathrm{P}[\mathrm{P} 04443793]$ photo! • Cueva dde Los Chorros près dde Riopar; alt. 1000m; 03 Jun. 1978 ; Bernard de Retz 77390; P[P06889416] photo! • Fábricas de S. Juán. Chorros del Río Mundo.; WH4956; Pared coliza rezumante.; 05 Jul. 1987; Valdés \& Herranz s. n.; ALBA[5246] photo! • "Los Chorros" Nacimiento del Mundo; 06 Sep. 1950; S. Rivas Goday \& A. Monasterio s. n.; MAF[33498] photo! • Los Chorros pr. Riopar in Reg. Murc.; in cataratas; 18 Jul. 1923; Cuatrecasas s. n.; BC[BC-53051] photo! •Ib.; 18 Jul. 1923; Cuatrecasas s. n.; BC[BC-53051_a] photo! • Nacimiento del Mundo en Riopar, Los chorros del Rio Mundo, sub El Calar del Mundo; 10 Jul. 1971; S. Rivas Goday, Ladero, Valdés, Borja s. n.; MAF[83307] photo! • Nacimiento del Rio Mundo; 04 Jun. 1959; Rivas Goday, Delgado y Monsterio s. n.; MAF[82726] photo! - Nacimiento del Rio Mundo en Riopar; 18 Jul. 1951; S. Rivas Goday s. n.; MAF[80015] photo! • pr. Riópar, Sierra del Calar del Mundo, nacimiento del rio Mundo, Cueva de los Chorros; alt. 1200 m; 15 Jun. 1993; R. Zamora s. n.; holotype: GDAC [37729] photo! • Riopar, Chorros del Rio Mundo; Taludes rezumantes cerca de una cascada; 15 May 2008; Alonso Verde s. n.; ALBA[6860] photo! • Riopar, Cueva de los Chorros; calizas; 28 Jun. 1988; Aparicio, F. García \& Silvestre s. n.; MA[MA-01-00485659] photo! • Riopar, Los Chorros del Mundo; 30S.WH.49.56; 1200 m; Tobas calizas rezumantes; 19 Jul. [19]86; Jose M. ${ }^{\circ} \mathrm{Her}$ ranz s. n.; MA[MA-01-00361018] photo! • Sa de Alcaraz. Riópar. Subida a la Cueva de los Chorros (Calar del río Mundo); Comunidades briocormofíticas en taludes rezumantes junto a escorrentías permanentes (Eucladio-Pinguiculetum vallisneriifoliae); 17 Jun. 1982; D. Sánchez-Mata, P. Cantó, S. Laorga \& D. Belmonte s. n.; MAF[110181] photo! • Sierra de Alcaraz, Calar del Mundo; 30S WH4956; 1150m; Fisuras calizas rezumantes; 20 Jul. 1984; M. Luceño s. n.; MA[MA-01-00439052] photo! • Sierra de Alcaraz, loco dicto "Los Chorros"; 30 S WH 4956; ad 1.100m; in scopulis humidis ad cataractam; 28 May 1976; J. Fernández Casas, J. Fernández Piqueras, M. T. Palomeque et M. E. Sánchez García 1154; BC[BC-626256] photo! - Ib.; 28 May 1976; J. Fernández Casas, J. Fernández Piqueras, M. T. Palomeque et M. E. Sánchez García 1154; MA[MA-01-00208452] photo! • Ib.; 28 May 1976; J. Fernández Casas, J. Fernández Piqueras, M. T. Palomeque et M. E. Sánchez García 1154; MA[MA-02-00208452] photo! - Ib.; 28 May 1976; J. Fernández Casas, J. Fernández Piqueras, M. T. Palomeque et M. E. Sánchez García 1154; MA[MA-01-00354192] photo! • Ib.; 28 May 1976; J. Fernández Casas, J. Fernández Piqueras, M. T. Palomeque et M. E. Sánchez García 1154; MA[MA-01-00421980] photo! • Ib.; 28 May 1976; J. Fernández Casas, J. Fernández Piqueras, M. T. Palomeque et M. E. Sánchez García 1154; MAF[150816] photo!.

Populations visited by the author:

SPAIN - Albacete • Riópar, Nacimiento del Río Mundo; 12 Aug. 2008; Aymeric Roccia, pers. observ. Ib.; 14 May 2010; Aymeric Roccia's pers. observ.

Photographs examined:

SPAIN - Albacete • Calar del Río Mundo; 2014; Enric Marti's pers. observ. • Cueva de los Chorros; 21 May 2000; Oliver Gluch's pers. observ. • Ib.; 18 Jul. 2004; Oliver Gluch's pers. observ. • Nacimiento del Río Mundo; Aug. 1995; Serge Lavayssière's pers. observ. • Ib.; Apr. 2003; Eric Partrat's pers. observ. • Ib.; 07 May 2010; Jean-Marc Moingeon’s pers. observ.

\section{Pinguicula sp.:}

Herbarium vouchers:

SPAIN - Guadalajara - Checa, turbera junto a la pista del Tajo; 30TXK006745; 1530 m; 25 Jun. 1997; L. M. Ferrero \& L. Medina LM718; MA[MA-01-00589325] photo!. 
Populations visited by the author:

SPAIN - Cuenca • Tragacete, Ojuelos de Valdeminguete; 1585 m; 19 May 2010; Aymeric Roccia's pers. observ.

Photographs examined:

SPAIN - Teruel - Iglesuela del Cid, barranco de la Tosquilla; $1280 \mathrm{~m}$; ladera caliza umbrosa con bosque mixto; s. d.; Silvia López Udias’ pers. observ.

\section{Discussion}

Pinguicula casperiana has been treated diversely in the past. In Blanca et al. (1999) and the subsequent chapter of Flora Iberica (Blanca 2001), it was considered as northern populations of $P$. mundi. However, as stated above in the diagnosis, it can be morphologically distinguished by leaf, flower, fruit and seed characters (Figs. 2 \& 4). Later, Roccia et al. (2016) treated these populations as $P$. dertosensis, but $P$. casperiana also differs from this last one by a number of vegetative, floral and reproductive diagnostic characters described in the diagnosis (Fig. 2). Thus P. casperiana truly represents a morphologically distinct species in the Iberian Peninsula, further supported by its geographically distinct distribution range (Fig. 3).

Pinguicula casperiana chromosome number was first studied by Casper \& Stimper (2009), based on material from the Hoz de Beteta (quoted as P. cf. vulgaris "Hoz de Beteta"). With 2n =64, it is an octoploid species and cannot be caryologicaly discriminated from Pinguicula dertosensis and Pinguicula mundi. Those two were first reported as hexaploid species (Zamora et al. 1996), but Casper \& Stimper (2009) have not been able to confirm these results. It was then hypothesized that they all three belong to a "P. vulgaris-like" group of species from central Spain (Casper \& Stimper 2009). However, a recent ITS-based molecular phylogeny study showed that $P$. dertosensis and $P$. mundi are well separated within the phylogenetic tree of European species, belonging to E1a and E3a subclades, respectively (De Castro et al. 2016). The recently described $P$. saetabensis, another species from Central Spain, is phylogenetically related to $P$. mundi (Crespo et al. 2018). Unfortunately, $P$. casperiana samples were not included in those two studies. Studying DNA material of $P$. casperiana would show if it is more related to P. dertosensis or to P. mundi.

The exact expansion to the east of Pinguicula casperiana has still to be explored. As said before, no population in the Teruel part of the Serranía de Cuenca has been found during fieldtrips, in the herbaria or in the literature. However, some locations exist between the Serranía de Cuenca and the Massís dels Ports and have to be investigated to decipher if they belong either to $P$. casperiana, $P$. dertosensis or another species. For example, the population in Iglesuela del Cid (Teruel province) has been a matter of debate. It was long thought to be $P$. dertosensis, but a recent report discards this possibility and rather assigns it to $P$. vulgaris (López Udias et al. 2016). However, such populations have not been visited by the author for the present study. Photographs sent by López Udias (pers. comm., 2020) depict a phenotype closer to $P$. vulgaris than to $P$. casperiana or $P$. dertosensis, but somehow peculiar compared to "typical" $P$. vulgaris. Such populations have to be investigated in a geographically wider study, especially comparing it to P. vulgaris L. var. alpicola Rchb., sensu Legendre et al. (2014).

A similar matter appears when it comes to the swampy populations of Pinguicula, in the Montes Universales, around the triple point Cuenca/Guadalajara/Teruel. The voucher MA-01-00589325 was identified as belonging to $P$. mundi in Blanca et al. (1999). This voucher was made from a fruiting specimen. However, the seedpod does not correspond neither to P. casperiana nor to P. mundi, but could match to the one of $P$. dertosensis. One population, at the Rio Júcar source, has been 
investigated for the present study. Flowers in fact look intermediate between $P$. casperiana and $P$. vulgaris. It can be hypothesized that $P$. casperiana actually represents the saxicolous populations of the Serranía de Cuenca, while another possible new taxon occupies the swampy areas of the Montes Universales, but this point still has to be more closely investigated. In this respect, additional populations assigned to P. vulgaris in literature and herbarium vouchers, growing in the surroundings, would need to be investigated too.

\section{Additional comments and discussion}

As can be seen in this extract, this article was in full agreement with Crespo et al.'s (2020) opinion that Pinguicula casperiana is a distinct species from $P$. dertosensis and P. mundii and it gave additional diagnostic characters to discriminate them. Of course, although not explicated, "P. conquensis" was also considered to be different from the superficially similar $P$. vallisneriifolia and $P$. saetabensis. However, I do not consider $P$. submediterranea and $P$. tejedensis as distinct entities from $P$. dertosensis. Although it was one point I also thought to address in my article, I was not able to find any significant diagnostic character after reviewing many vouchers and pictures. The main morphological difference of $P$. submediterranea claimed by Crespo et al. (2020) is the smaller size of the plants in all aspects. In table 1, Pinguicula tejedensis and P. submediterranea seedpods are claimed to be oblongovoid, the which I cannot confirm from voucher and picture examination and from their figure 1 (see also Figure 2 in this article for comparison with $P$. dertosensis). The difference in seed shape is also not obvious (compare their figure 4 with Figure 2 in this article for comparison with $P$. dertosensis). Thus, $P$. submediterranea and P. tejedensis can be regarded as later synonyms of $P$. dertosensis.

The main focus of Crespo et al.'s study (2020) is on molecular phylogeny. Pinguicula casperiana is genetically closely related to $P$. dertosensis, but, as seen above, it is morphologically distinct. Pinguicula submediterranea and $P$. tejedensis appear genetically distant from $P$. dertosensis, although they are morphologically identical. A similar matter already occurred when describing $P$. lattanziae (De Castro et al. 2016). Unfortunately, Crespo et al. (2020) did not describe their protocol in the material and methods, but seemingly used the same as they did in Crespo et al. (2018), which is based on De Castro et al.'s (2016) material and methods. Sanger sequencing is problematic when analyzing nuclear markers of polyploid organisms. The obtained sequence is a mix of several (up to eight in the case of this group of octoploid butterwort species) sequences and thus the final result greatly depends on the interpretation of the person who analyzes the raw data. This experimenter bias will therefore also affect the subsequent molecular phylogeny analysis. Although nuclear markers will probably prove to be very useful, recent results have shown the limits of the currently applied method that is only able to discriminate groups of species, but has to be considered very cautiously at the species level. As it is, such analyses may be used to support morphological differences, but should not be the base for describing new species. A different experimental method should lead to more significant results. I designed such a protocol (unpubl.) but I hadn't yet the opportunity to apply it to butterworts. However, independent similar experiments gave interesting results on ferns (Rothfels et al. 2017), moonworts (Dauphin et al. 2018) and quillworts (Grigoryan et al. 2020), for example.

Acknowledgements: Eric Partrat and Laurent Legendre are thanked for useful fieldtrip pictures and accession to cultivated material. Eric Partrat is also thanked for useful discussions about $P$. casperiana. Iwein Coppens was part of the 2010 fieldtrip is thanked for driving long way down to Spain. Oliver Gluch is thanked for providing one picture to complete Fig. 4. ALBA, BC, GADC, JACA, MA and MAF curators are thanks for their kind assistance in examine their vouchers. 


\section{References}

Blanca, G. 2000. Pinguicula L. In: Paiva, J., Sales, F., Hedge, I.C., Aedo, C., Aldasoro, J.J., Castroviejo, S., Herrero, A., and Velayos, M. (eds.). Flora iberica 14. Real Jardin Botanico, CSIC, Madrid, Spain, pp. 81-95.

Blanca, G., Ruiz-Rejon, M., and Zamora, R. 1999. Taxonomic revision of the genus Pinguicula L. in the Iberian Peninsula. Folia Geobotanica 34: 337-361.

Casper, S.J. 2019. The insectivorous genus Pinguicula (Lentibulariaceae) in the Greater Antilles. Botanic Garden and Botanical Museum Berlin, Freie Universität, Berlin.

Casper, S.J., and Stimper, R. 2009. Chromosome numbers in Pinguicula (Lentibulariaceae): survey, atlas, and taxonomic conclusion. Plant Systematics and Evolution 277: 21-60.

Casper, S.J., Bussmann, R.W., and Henning, T. 2020. Pinguicula rosmarieae Casper, Bussmann \& T. Henning (Lentibulariaceae), a new butterwort from the Amotape-Huancabamba Zone (northern Peru). Phytokeys 140: 107-123.

Crespo, M.B., Martínez-Azorín, M., and Alonso-Vargas, M.Á. 2018. Morphological and molecular data support recognition of a new rupicolous species of Pinguicula (Lentibulariaceae) from the Iberian Peninsula. Plant Biosystems, An International Journal Dealing with all Aspects of Plant Biology 153(1): 77-87.

Crespo, M.B., Martínez-Azorín, M., Alonso, M.Á, and Lorenç, S. 2020. Two new calcicolous species of Pinguicula sect. Pinguicula (Lentibulariaceae) growing on rocky hábitats of the Iberian Peninsula. Phytotaxa 456(3): 269-284.

Dauphin, B., Grant, J.R., Farrar, D.R., and Rothfels, C.J. 2018. Rapid allopolyploid radiation of moonwort ferns (Botrychium; Ophioglossaceae) revealed by PacBio sequencing of homologous and homeologous nuclear regions. Molecular Phylogenetics and Evolution 120: 342-353.

De Castro, O., Innangi, M., Di Maio, A., Menale, B., Baccheta, G., Pires, M., Noble, V., Gestri, G., Conti, F., and Peruzzi, L. 2016. Disentangling phylogenetic relationships in a hotspot of biodiversity: the butterworts (Pinguicula L., Lentibulariaceae) endemic to Italy. PloS ONE 11(12): e0167610.

Fleischmann, A., and Roccia, A. 2018. Systematics and evolution of Lentibulariaceae: I. Pinguicula. In: Ellison, A.M., and Adamec, L. (eds.). Carnivorous Plants: Physiology, Ecology, and Evolution. Oxford University Press, Oxford, United Kingdom, pp. 70-80.

Juárez-Gutiérrez, H.D., Muñiz-Castro, M.Á, Hernández-Rendón, J., and Nuño-Rubio, A.T. 2018. Pinguicula zamudioana (Lentibulariaceae) a new species endemic to western Mexico. Phytotaxa 372(4): 243-255.

Grigoryan, M.Y., Bobrov, A.A., Brunton, D.F., Volkova, P.A., Logacheva, M.D., and Neretina, T.V. 2020. Next generation DNA sequencing reveals allopolyploid origin of decaploid Isoëtes lacustris (Isoëtaceae). Aquatic Botany. https://doi.org/10.1016/j.aquabot.2020.103326.

IUCN. 2012. IUCN Red List categories and criteria. Version 3.1, ed. 2. International Union for Conservation of Nature, Gland, Switzerland, and Cambridge, United Kingdom.

Legendre, L., Tison, J.-M., and Roccia, A. 2014. Pinguicula L. In: Tison, J.-M., and de Foucault B. (eds.). Flora gallica. Flore de France. Biotope, Mèze, France, pp. 820-822.

López Udias, S., Fabregat Llueca, C., Fabado Alós, J., and Picornell Segura, E. 2016. Nuevos datos para la flora de Aragón, II. Flora Montiberica 64: 20-25.

Roccia, A., Gluch, O., Lampard, S., Robinson, A., Fleischmann, A., McPherson, S., Legendre, L., Partrat, E., and Temple, P. 2016. Pinguicula of the temperate North. Redfern Natural History Productions, Poole, Dorset, United Kingdom. 
Rothfels, C.J., Pryer, K.M., and Li, F.-W. 2017. Next-generation polyploid phylogenetics: rapid resolution of hybrid polyploid complexes using PacBio single-molecule sequencing. New Phytologist 213: 413-429.

Thiers, B. continuously updated. Index Herbariorum: a global directory of public herbaria and associated staff. New York Botanical Garden's virtual herbarium. Available from http://sweetgum. nybg.org/ih/ [accessed 21 April 2020].

Zamora, R., Jamilena, M., Ruiz Rejón, M., and Blanca, G. 1996. Two new species of the carnivorous genus Pinguicula (Lentibulariaceae) from Mediterranean habitats. Plant Systematics and Evolution 200: 41-60.

Zamudio, S., and Vega, H. 2019. Una nueva especie de Pinguicula (Lentibulariaceae) de Honduras. Phytoneuron 53: 1-6.

Zamudio, S., Salinas-Rodríguez, M.M., Quirino-Olvera, R., and Hernández-Rendón, J. 2019. Pinguicula simulans (Lentibulariaceae), a new species from Nuevo León, Mexico. Phytotaxa 424(1): 049-055.

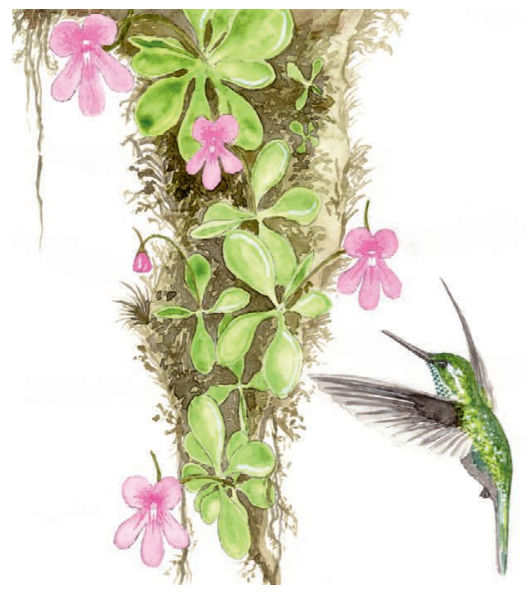

\section{A garden's chronicle Botanical illustrations}
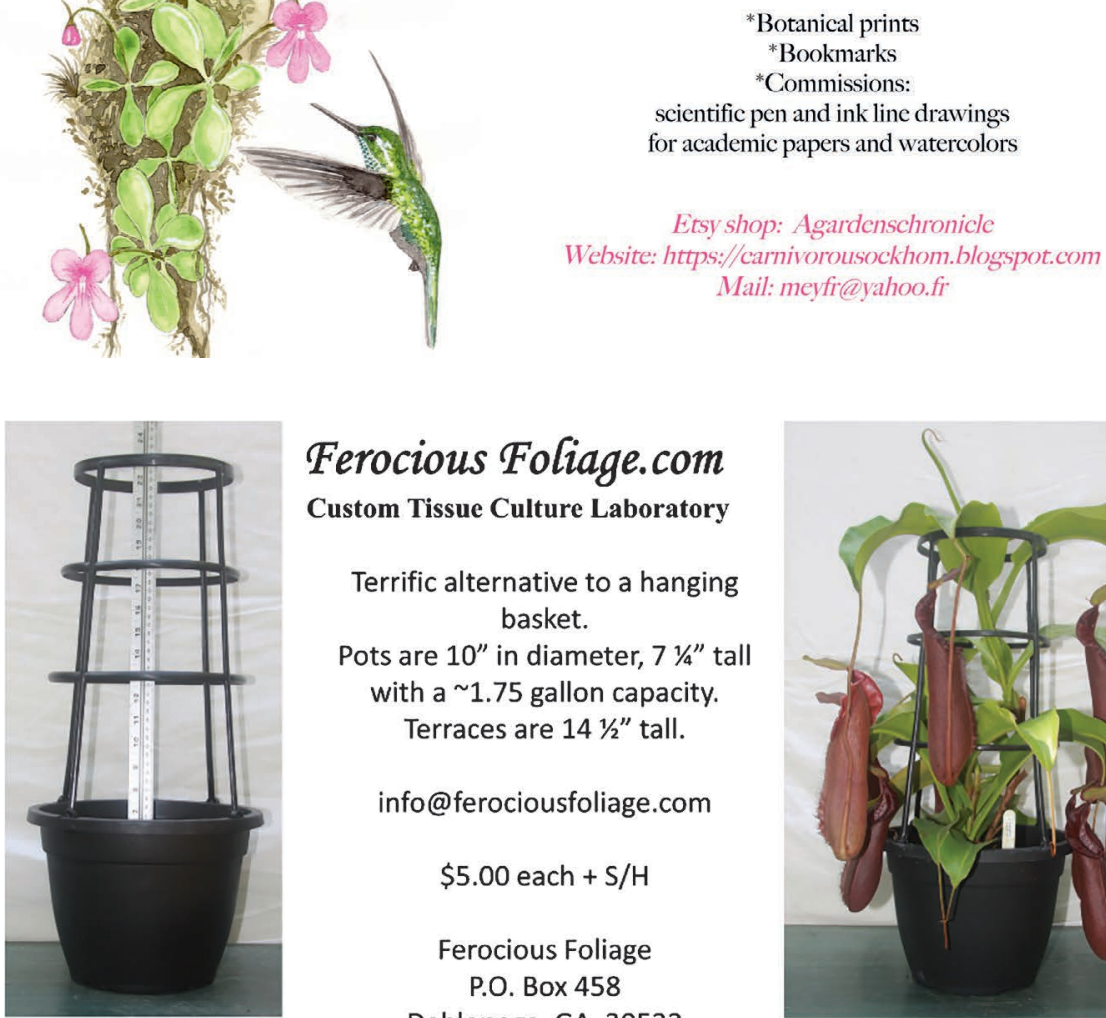

\section{Ferocious Foliage.com}

Custom Tissue Culture Laboratory

Terrific alternative to a hanging basket.

Pots are $10^{\prime \prime}$ in diameter, $71 / 4^{\prime \prime}$ tall with a $\sim 1.75$ gallon capacity.

Terraces are $141 / 2 "$ tall.

info@ferociousfoliage.com

$\$ 5.00$ each $+\mathrm{S} / \mathrm{H}$

Ferocious Foliage

P.O. Box 458

Dahlonega, GA 30533

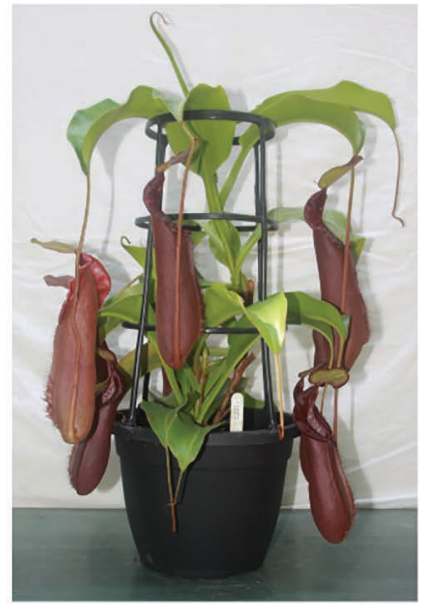

Plant not included 